ISSN 1991-

Website: http://jsci.utq.edu.iq

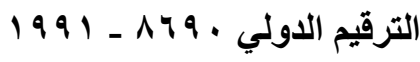

ocon

\title{
Determination of Radon Exhalation Rates from Tiles (Marble, Granite and Ceramic) Using LR115 Type II Passive Technique
}

\author{
H.Bakr \\ Department of Physics - College of Education- University of Basrah
}

\begin{abstract}
$\underline{\text { Abstract }}$
Exhalation of ${ }^{222} \mathrm{Rn}, \alpha$-radioactive inert gas, is associated with the presence of ${ }^{226} \mathrm{Ra}$ and it's ultimate precursor uranium in the earth crust. It is a useful quantity to compare the relative importance of different materials of tiles (marble, granite and ceramic). Majority of new houses in Basrah (Iraq) are using tiles. Therefore, studies concerning the determination of radon exhalation rate from there materials were carried out using LR-115 Type II passive technique in this content, the Solid State Nuclear Track Detectors(SSNTDs) with a plastic container('can' technique) were applied .There container were hermetically sealed and stored for 120 days to attain equilibrium between ${ }^{222} \mathrm{Rn}$ and ${ }^{226} \mathrm{Ra}$. After exposure to radon, LR115 type II detectors were etched in $2.5 \mathrm{~N} \mathrm{NaOH}$ solution at $60^{\circ} \mathrm{C}$ for $2 \mathrm{~h}$. From the measured radon concentration values, ${ }^{222} \mathrm{Rn}$ exhalation rates were determined. The average values of exhalation rates for radon has been found of values $\left(0.225,1.529,16.196 \mathrm{~Bq} \mathrm{~m}^{-2} \mathrm{~h}^{-1}\right)$ for marble, ceramic and granite respectively. Exhalation rates for granite has been found to be several times higher than that for marble and ceramic. The results of the measurement has been discussed.
\end{abstract}




\section{Introduction}

Home construction materials can be significant sources of indoor radon in addition to soil and water. Most materials contain ${ }^{238} \mathrm{U}$ are consequently potential radon emitters, since ${ }^{222} \mathrm{Rn}$ is a daughter product of ${ }^{226} \mathrm{Ra}$ which in turn is derived from the longer-lived antecedent ${ }^{238} \mathrm{U}$. However, some materials have higher concentration of ${ }^{238} \mathrm{U}$ and ${ }^{226} \mathrm{Ra}$ such as alum shale and black shale [1-3].

Radon, thoron and their decay products are alpha, beta and gamma-emitting nuclei. Inhalation of these radio- nuclides represent the main source of exposure to ionizing radiation for population in most countries [4-6].

Due to its half-life time relative to other isotopes, radon $\left({ }^{222} \mathrm{Rn}, \mathrm{T}_{1 / 2}=3.82 \mathrm{~d}\right)$ [7] which is a descendent of ${ }^{238} \mathrm{U}$ is considered to be the most significant isotope of radon problem in the environmental studies. Trace particle, of ${ }^{238} \mathrm{U}$ are found in most natural rocks. The acidic magmatic rocks such as granite contair, in general, more radioactive elements than sedimentary rocks, and the latter contain more than basic magmatic rocks such as basalt. Uranium has affinity to some materials such as phosphates, coal, oil shale etc. Basrah has rich oil shale deposits and thus it is likely to have high values of Uranium and radon [7].

Measurement of radon are of importance because the radiation dose to human population due to inhalation of radon and it's daughters contributes more than $50 \%$ of the total dose from natural source [9]. The three radon isotopes $\left({ }^{219} \mathrm{Rn}\right.$ $\left.,{ }^{220} \mathrm{Rn},{ }^{222} \mathrm{Rn}\right)$ are gaseous . They may be released from the ground, rocks and also from tiles and accumulate with their short lived daughters in closed spaces, and in particular in dwellings, ${ }^{219} \mathrm{Rn}$ and ${ }^{220} \mathrm{Rn}$, mainly because of their short half-life are not as important as ${ }^{222} \mathrm{Rn}$, which may reach levels of concentration in the air which are signification in terms of radiological protection. The dose deriving from the presence in the air of ${ }^{22} \mathrm{Rn}$ is linked to the inhalation of the short lived daughters, which are deposited in the respiratory organs, if deeply inhaled, emit alphaparticles in direct contact with the bronchial and pulmonary epithelium. For these reasons, the dose deriving from the exposure to ${ }^{222} \mathrm{Rn}$ enclosed spaces has been placed in direct relation to the risk of lung cancer [10]. The epidemiological evidence for the induction of lung cancer following inhalation of radon comes from several cases studies of underground miners.

In particular ${ }^{222} \mathrm{Rn}$ poses a major concern in regard to radiation pollution and human health hazard [11]. The radon gas can diffuse easily out of the soil surface into air or houses; it can be trapped in poorly ventilated houses and so it's concentration can build up to higher levels. Although soil is considered to the main source of indoor radon concentration, raw building materials and tiles (especially quartz, cement, granite, etc) can make a significant contribution to the level of natural radioactivity in closed such as stores and badly-ventilated dwelling [12]. Moreover, the production rate of radon in dwellings depends on the concentration of radium content in the subsoil, building material, and porosity as well as the density of the wall and tiles material $[13,14]$. A number of studies of exhalation rates of radon / thoron from soil and building materials are available.

Radon and thoron decay products have been measured in the air by beta-counting using on end-window Geiger-Muller counter[7]. This technique has some limits and draw backs. Alpha-counting applied for measured the concentration of radon 
and thoron progenies presents some disadvantages such as the absorption of alpha-particles and degradation of alphaparticles energy in the membrane filter of the counter. The use of gamma-ray spectrometry of measuring radon and thoron decay product concentrations in air suffers from some disadvantages such as low efficiency, high back ground and high cost.

This study of radon activity in tiles being carried out by using super grade economical and reliable method and we describe a "can technique" based on calculating the number of tracks for an $\alpha$ particle coming from radon, thoron and their daughters to be registed on LR115 type II and exploiting the resulting track densities for determining the radon exhalation rates in different tiles.

Radon exhalation from building materials has been the subject of many studies[15,16]. If building material are a significant source of radon in a house, a remedial action has been proposed to reduce it in addition to ventilation [1].

Iraq is becoming a relatively big market foreign granite, marble and ceramic usage. New particles have been introduced in house construction, among these is the tilling of houses. It is, therefore importance to study the exhalation of radon from these building material. LR115 type II nuclear detector has been intensively used in radon dosimetry . Therefore, in the present study will use LR115 type II which we believe will yield promising results. It is perhaps the simplest and cheapest methods of determining the exhalation rates.

The present study describes the measurements of radon exhalation from tiles using passive technique.

\section{Method of study}

Radon exhalation rate measured by using passive Solid State Nuclear Track Detectors (SSNTD) technique. The dosimeter used in this study consisted of a Kodak LR115 type II [6] cellulose nitrate plastic showed it's potential in measuring alpha emission for detection of alpha particles from radon and it's daughters. The LR115 type II film has a cellulose nitrate layer $13 \mu \mathrm{m}$ thick on an inert polyester base of thickness $100 \mu \mathrm{m}$. The cellulose nitrate is the active part for the detection of alpha particles.

Sample of marble, granite and ceramic tiles were collected from local suppliers. They were twelve marble, six granite, six ceramic of different origins, Italian, Spanish, Chinese, Turkian, Indian, Pakistani, Iranian, Oman, Syrian and UAE.

The "can technique" was used for the long-term measurement of radon exhalation rates from the tiles $[1,13]$. In this technique, LR115 type II (of dimensions $2 \times 2 \mathrm{~cm}^{2}$ ) was placed at $3 \mathrm{~mm}$ height on a diaphragm between it and the surface of the tile and surrounded by a small impervious vessel sealed with silicon sealant placed around the detector [17] as shown in figure(1).

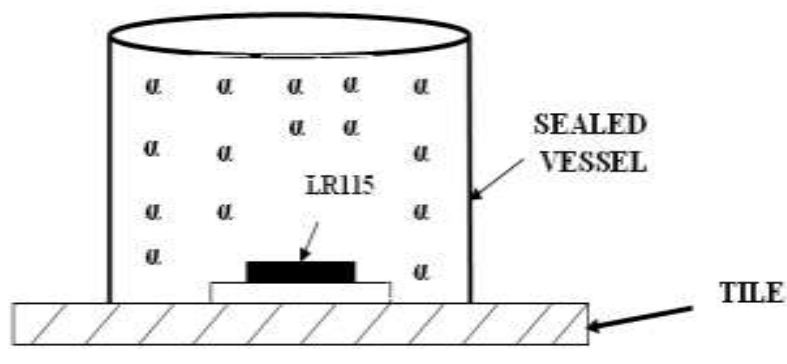

Figure (1):-showing the setup where LR115 is placed on the surface of a tile on top of a diaphragm and surrounded by a sealed vessel 
The vessel was $6.3 \mathrm{~cm}$ diameter and $4 \mathrm{~cm}$ height. The upper faces of the detector records the decay of radon and it's progeny in the 'can'. Radon and it's progeny in the 'can' would reach equilibrium concentration after 3 hours. The detector, were left in the sealed vessel for a period of 120days. They were there removed and etch chemically in $\mathrm{NaOH}$ solution $\left(2.5 \mathrm{~N}\right.$ at $60^{\circ} \mathrm{C}$ for $2 \mathrm{~h}$.). The track densities in the (SSNTD)was measured menially by means of optical microscope .The recorded track density was then converted in $\left(\mathrm{Bq}^{-}\right.$ ${ }^{3}$ ) by appropriate calibration factor [18-19] and the exhalation rates was calculated by the equation [20] :-

$$
E_{x}=\frac{C V \lambda / A}{T+\frac{1}{\lambda}\left(e^{-\lambda T}-1\right)},
$$

where : $E_{x}$ is the radon exhalation rate $\left(\mathrm{Bq} \mathrm{m} \mathrm{m}^{-2} \mathrm{~h}^{-1}\right), \mathrm{C}$ is the integrated radon exposure as measured by LR115 type II film

$\left(\mathrm{Bq} \mathrm{m}^{-3} \mathrm{~h}^{-1}\right), \mathrm{V}$ is the effective volume of plastic container $\left(\mathrm{m}^{3}\right), \mathrm{A}$ is the surface area of the tile covered by the 'can' $\left(\mathrm{cm}^{2}\right), \lambda$ is the decay constant for radon $\left(7.56 \times 10^{-3} \mathrm{~h}\right.$ ${ }^{1}$ ), and $\mathrm{T}$ is the exposure time in (h)

\section{Result and Discussion}

Radon exhalation was measured for each tile using passive technique by LR115 type II. Table (1), shows the sample number, the origin countries, the measured track density, radon concentration and the exhalation rate in all samples under investigation. The radon exhalation rate per unit area $\left(E_{x}\right)$ of twelve marble samples varied from
(0.060 Bq m $\left.\mathrm{m}^{-2} \mathrm{~h}^{-1}\right)$ for Italian marble to $\left(0.59 \mathrm{~Bq} \mathrm{~m}^{-2} \mathrm{~h}^{-1}\right)$ for Iranian marble with an average of $\left(0.225 \mathrm{~Bq} \mathrm{~m}^{-2} \mathrm{~h}^{-1}\right)$ (see figure (2)).

The radon exhalation rate per unit area $\left(E_{\mathrm{x}}\right)$ of five granite samples varied from $\left(0.556 \mathrm{~Bq} \mathrm{~m}^{-2} \mathrm{~h}^{-1}\right)$ for Italian granite to $\left(51.97 \mathrm{~Bq} \mathrm{~m}^{-2} \mathrm{~h}^{-1}\right)$ for Chinese (3) granite with an average of (16.196 $\left.\mathrm{Bq} \mathrm{m}^{-2} \mathrm{~h}^{-1}\right)$

(see figure (3)).

The radon exhalation rate per unite area $\left(E_{x}\right)$ of six ceramic samples varied from $\left(0.274 \mathrm{~Bq} \mathrm{~m}^{-2} \mathrm{~h}^{-1}\right)$ for Syrian ceramic to (3.691 $\mathrm{Bq} \mathrm{m}^{-2} \mathrm{~h}^{-1}$ ) for Chinese (2) ceramic with an average of $(1.529 \mathrm{~Bq}$ $\mathrm{m}^{-2} \mathrm{~h}^{-1}$ ) (see figure (4)). 
Table(1): radon exhalation rates and track production rates from different tiles.

\begin{tabular}{|c|c|c|c|c|}
\hline $\begin{array}{l}\text { Sample } \\
\text { No. }\end{array}$ & Tile type & Origin & $\begin{array}{c}\text { Track density } \\
\left(\text { Track } \mathrm{cm}^{-2} \text { day }^{-1}\right)\end{array}$ & 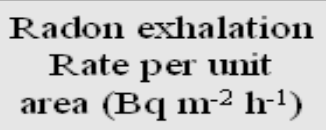 \\
\hline 1 & Marble & Italian & 0.52 & 0.060 \\
\hline 2 & Marble & Turkian (1) & 0.57 & 0.066 \\
\hline 3 & Marble & Turkian (2) & 0.62 & 0.071 \\
\hline 4 & Marble & Turkian (3) & 0.73 & 0.084 \\
\hline 5 & Marble & Pakistani (1) & 0.81 & 0.093 \\
\hline 6 & Marble & Pakistani (2) & 0.79 & 0.091 \\
\hline 7 & Marble & Pakistani (3) & 3.24 & 0.373 \\
\hline 8 & Marble & Pakistani (4) & 4.92 & 0.567 \\
\hline 9 & Marble & Oman & 0.59 & 0.068 \\
\hline 10 & Marble & Indian (1) & 4.67 & 0.54 \\
\hline 11 & Marble & Indian (2) & 0.86 & 0.10 \\
\hline 12 & Marble & Iranian & 5.12 & 0.59 \\
\hline 13 & Granite & Italian & 4.83 & 0.556 \\
\hline 14 & Granite & Chinese (1) & 9.50 & 1.094 \\
\hline 15 & Granite & Chinese (2) & 64.78 & 7.462 \\
\hline 16 & Granite & Chinese (3) & 451.32 & 51.97 \\
\hline 17 & Granite & Iranian & 172.76 & 19.9 \\
\hline 18 & Ceramic & Spanish & 9.50 & 1.094 \\
\hline 19 & Ceramic & Chinese (1) & 14.40 & 1.659 \\
\hline 20 & Ceramic & Chinese (2) & 32.04 & 3.691 \\
\hline 21 & Ceramic & Iranian & 11.48 & 1.322 \\
\hline 22 & Ceramic & UAE & 9.85 & 1.134 \\
\hline 23 & Ceramic & Syrian & 2.38 & 0.274 \\
\hline
\end{tabular}

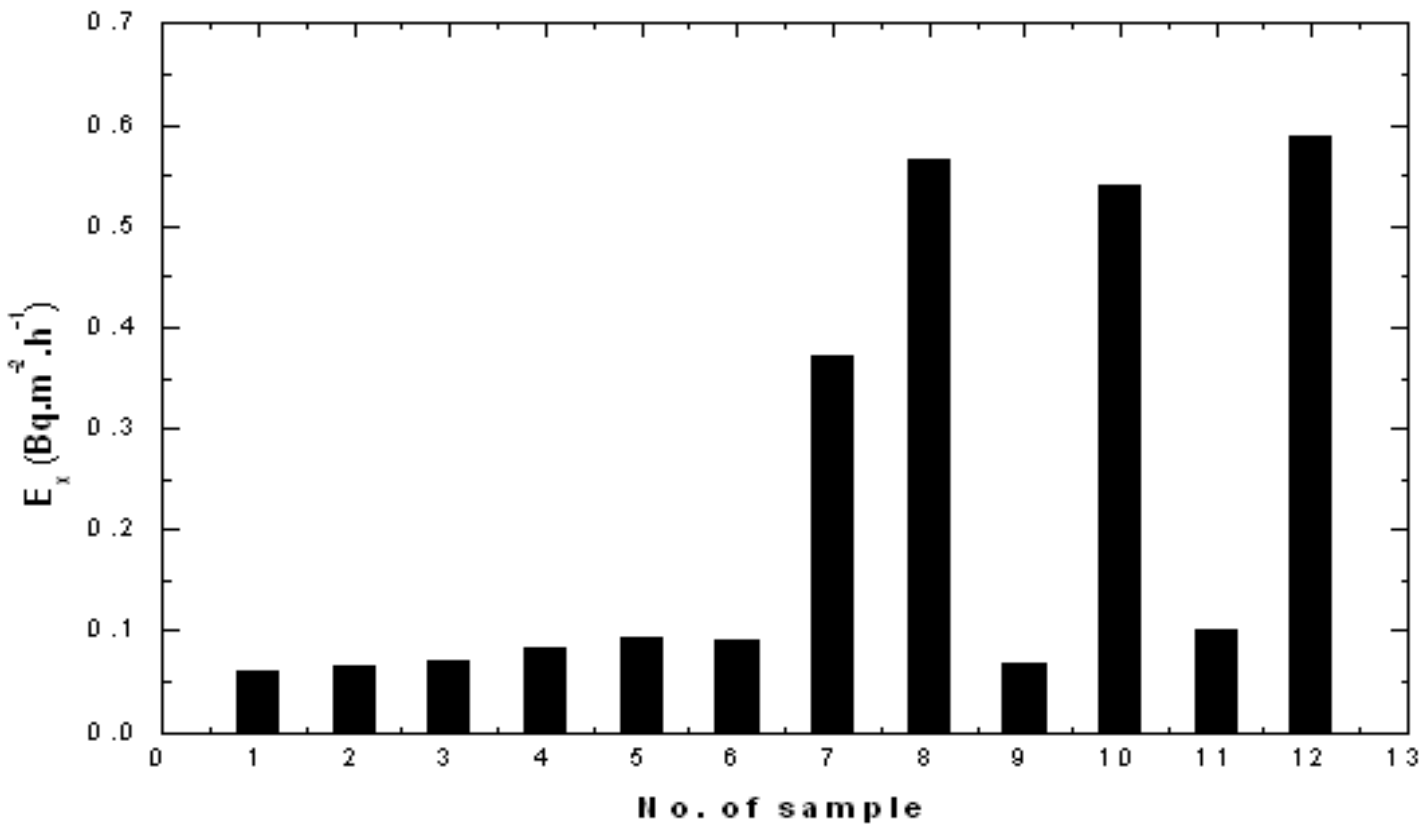

Figure (2): Radon exhalation rate per unit area $\left(E_{x}\right)$ from Marble of different origin (samples 1-12). 


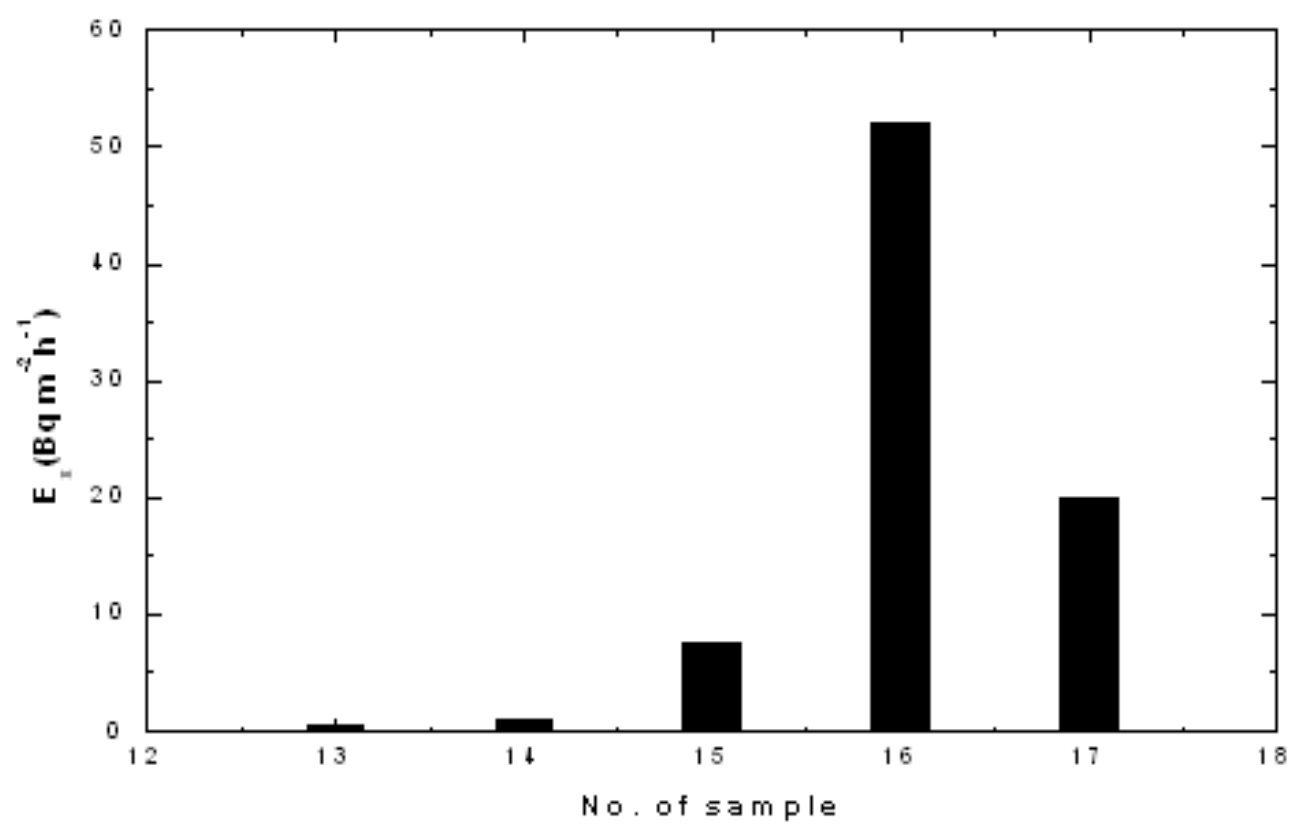

Figure (3): Radon exhalation rate per unit area $\left(E_{x}\right)$ from Granite of different origin (samples 13-17).

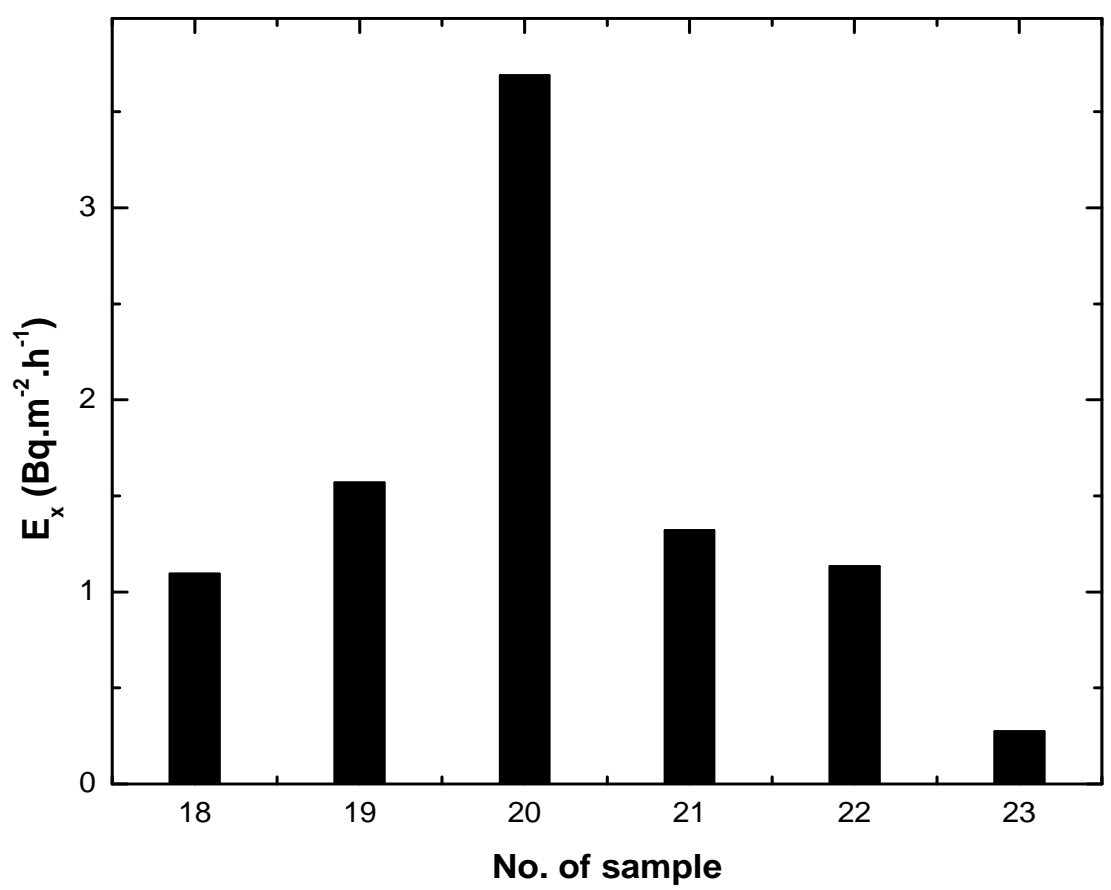

Figure (4): Radon exhalation rate per unit area $\left(E_{x}\right)$ for Ceramic of different origin (samples 18-23). 
The average radon exhalation rates of marble $\left(E_{x}=0.225 \mathrm{~Bq} \mathrm{~m}^{-2} \mathrm{~h}^{-1}\right)$ and ceramic $\left(E_{x}=1.529 \mathrm{~Bq} \mathrm{~m}^{-2} \mathrm{~h}^{-1}\right)$ were below the average radon exhalation rates of granite $\left(E_{x}=16.196 \mathrm{~Bq} \mathrm{~m}^{-2} \mathrm{~h}^{-1}\right)$, which caused by the different construction of the samples, and the nature of the crude material. We suggest to use the granite tiles out door only and don't use it indoor.

\section{Conclusion}

To conclude, passive measuring technique successfully applied to determined the radon exhalation rates from tiles sample collected from Basrah market.

Long term measurement of the tile surface shows promise for estimating average airborne radon and thoron progeny dose rates in houses. However it should be noted that estimated reduction of indoor radon concentration and the internal dose equivalent by the use of the various tiles shown in table (1).

The obtained results of exhalation rates are in good agreement with the previously reported data for a similar tiles by other workers $[6,17,20]$.

Italian tiles (marble and granite) are the best tiles for used because of the lowest radon exhalation rates than the other tiles

\section{$\underline{5 .}$ References}

[1] S.A. Durrani and R.Ilic ,(Eds), "Radon Measurement by Etch Track Detectors". World Scientific Publish Singapore (1997).

[2] M.A. Misdaq, H.Ouaba and M. Merzouki, Nucl. Instr. And Meth. in Phys. Res. B, 263(2007)105.
[3] M.Faheen, N.Mati and Matiullah, J. Radio. Prot., 27(2007)493.

[4] D.E. Cherouati, S.Diffal and S.A.Durrani;Nucl.TracksRadiat.Meas. 15(1988)583.

[5] M.Rokmy , M.A.misday and C.Saif, J.RadionalNucl.Chem. ,190(1995)51.

[6] M.A.Misdaq ,H.Ezzahery and J.Lamine ,J.Rdional-Nucl. Chem. 252(2002)6774

[7] B.A. AL-Bataina, A.M. Ismail, M.K. Kullab, k.M.Abumurad and H.Mustafa, Radiat. Meas. , 28(1997)591.

[8] N. Segovia, M.I. Gaso and M.A. Armienta, Environ Geochem Health, 29(2007)143.

[9] UNSCEAR, sources, Effect and Risks of Ionizing Radiation,United Nations Reports New York, USA (1988)

[10] ICRP Publication 50, "Lung cancer risk from indoor exposure due to daughters". Annals of the ICRP 17(1), oxford :pergemon (1987).

[11] UNSCEAR. Report, New York ;United Nations, (1993)45.

[12] F.I. Hassan, An-Najah Univ. J. for Reseach ,4(1996)92.

[13] M.M.. Abu-Samreh , The Arabian J. for Science and Engineering, 30(2005)343.

[14] Z. Pupp and S. Paroczy, Health Phys. ,72(1997)601.

[15] A. Savidou, C. Rapits and Kvitidis , J. Environ Radio. ,31(1996)21.

[16] F. Abu-Jarad, J.H. Fremlin and R. Bull, Phys. Meas. Biol.,25(1980)483. 
[17] M.I. Al-Jarallah, F. Abu-Jarad, FazalUr-Rehman, Radiation Meas. , 34(2001)491.

[18] V.M.Chouby andR.C.Ramola, Environ. Geology, 32(1997)258.
[19] R.C. Ramola and V.M. Chouby, J. Radional and Nucl Chem. 256(2003)219.

[20] N. Sharma, H.S. Virk, Radiat. Meas. ,34(2001)467.

تحديد انبعاثية غاز الر ادون من مو اد البلاط (المرمر و الكر انيت و السير اميك) بأستخدام التقنية LR-115 type II التر اكمية للكاثن التران

\author{
حمـزة بكـر سلمـان \\ قسم الفيزيـاء ــ كلية التربية - جامعة البصـرة
}

\begin{abstract}
الخلاصة
انبعاث غاز الرادون الخامل المصاحب له جسيمات الفا يرتبط بوجود الراديوم Ra اليورانبوم بكميات مختلفة في القترة الارضية ـ هناك فائدة كبيرة بمقارنة مواد مختلفة من البلاط (المرمر والكرانيت والسيراميك) المستخدم لأكساء أرضيات معظم المباني والمساكن الحديثة في محافظة البصرة (العراق). وبذللك اجريت

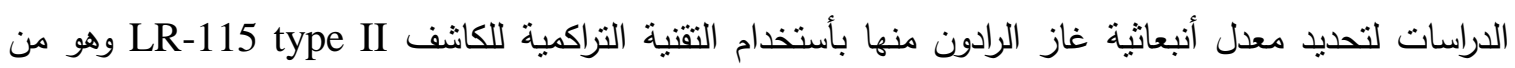
كواثف الاثر النووي الصلب (SSNTDs) ـ تقنية القدح المغلق استخدمت في هذه الدراســة ولمدة 120 يوم

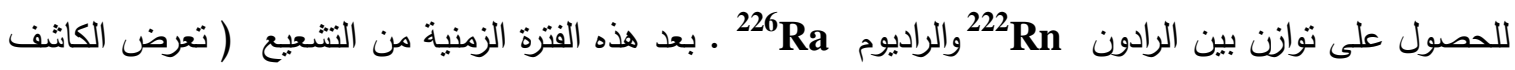
2.5 N NR-115 type II ودرجة حرارة 60 C 60 لمدة ساعتنن • نم تحديد انبعاثنة غاز الرادون بعد عملية القياسات المختبرية وحساب التركيز

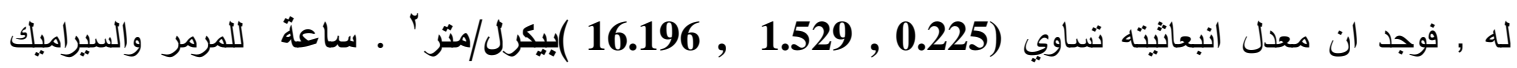

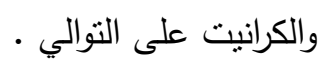
وجد ان انبعاثية غاز الرادون للكرانيت أعلى بكثير من انبعاثتيته لمادتي المردر والسيراميك. نوقثت نتائج هذه الدراسة واقترحت التوصيات للمعالجة.
\end{abstract}

